\title{
Canon Formation and the Reception of William Blake's and Dickinson's Poetry in Korea
}

\author{
Hyesook Son \\ Sungkyunkwan University
}

Follow this and additional works at: https://docs.lib.purdue.edu/clcweb

Part of the Comparative Literature Commons, and the Feminist, Gender, and Sexuality Studies Commons

Dedicated to the dissemination of scholarly and professional information, Purdue University Press selects, develops, and distributes quality resources in several key subject areas for which its parent university is famous, including business, technology, health, veterinary medicine, and other selected disciplines in the humanities and sciences.

CLCWeb: Comparative Literature and Culture, the peer-reviewed, full-text, and open-access learned journal in the humanities and social sciences, publishes new scholarship following tenets of the discipline of comparative literature and the field of cultural studies designated as "comparative cultural studies." Publications in the journal are indexed in the Annual Bibliography of English Language and Literature (Chadwyck-Healey), the Arts and Humanities Citation Index (Thomson Reuters ISI), the Humanities Index (Wilson), Humanities International Complete (EBSCO), the International Bibliography of the Modern Language Association of America, and Scopus (Elsevier). The journal is affiliated with the Purdue University Press monograph series of Books in Comparative Cultural Studies. Contact: <clcweb@purdue.edu>

\section{Recommended Citation}

Son, Hyesook. "Canon Formation and the Reception of William Blake's and Dickinson's Poetry in Korea." CLCWeb: Comparative Literature and Culture 16.6 (2014): <https://doi.org/10.7771/1481-4374.2531>

This text has been double-blind peer reviewed by $2+1$ experts in the field.

The above text, published by Purdue University Press @P Purdue University, has been downloaded 399 times as of 11/ 07/19.

This document has been made available through Purdue e-Pubs, a service of the Purdue University Libraries. Please contact epubs@purdue.edu for additional information.

This is an Open Access journal. This means that it uses a funding model that does not charge readers or their institutions for access. Readers may freely read, download, copy, distribute, print, search, or link to the full texts of articles. This journal is covered under the CC BY-NC-ND license. 


\section{PURDUE}

$\bar{U}$ N I V E R S I T Y UNIVERSITY PRESS < http://www.thepress.purdue.edu>

\section{CLCWeb: Comparative Literature and Culture}

ISSN 1481-4374 <http://docs.lib.purdue.edu/clcweb> Purdue University Press @Purdue University

CLCWeb: Comparative Literature and Culture, the peer-reviewed, full-text, and open-access learned journal in the humanities and social sciences, publishes new scholarship following tenets of the discipline of comparative literature and the field of cultural studies designated as "comparative cultural studies." In addition to the publication of articles, the journal publishes review articles of scholarly books and publishes research material in its Library Series. Publications in the journal are indexed in the Annual Bibliography of English Language and Literature (Chadwyck-Healey), the Arts and Humanities Citation Index (Thomson Reuters ISI), the Humanities Index (Wilson), Humanities International Complete (EBSCO), the International Bibliography of the Modern Language Association of America, and Scopus (Elsevier). The journal is affiliated with the Purdue University Press monograph series of Books in Comparative Cultural Studies. Contact: <clcweb@purdue.edu>

\section{Volume 16 Issue 6 (December 2014) Article 2 Hyesook Son, \\ "Canon Formation and the Reception of Blake's and Dickinson's Poetry in Korea" <http://docs.lib.purdue.edu/clcweb/vol16/iss6/2>}

Contents of CLCWeb: Comparative Literature and Culture 16.6 (2014) Special Issue Western Canons in a Changing East Asia. Ed. Simon C. Estok <http://docs.lib.purdue.edu/clcweb/vol16/iss6/>

Abstract: In her article "Canon Formation and the Reception of Blake's and Dickinson's Poetry in Korea" Hyesook Son examines a range of aspects with regard to the reception and scholarship of William Blake's and Emily Dickinson's poetry. Son demonstrates by what process these two poets have become canonized and what intellectual factors and ideologies have produced this canonization. The reception of Blake's and Dickinson's work has symptomatically displayed the characteristic Korean interpretive frames working through the last six decades and their limits and inherent possibilities. Today, Korean scholars are examining both their literary inheritance and reconstitute literary scholarship in general in order to reflect the shifting historical and cultural conditions to meet the need for change and diversity. 


\section{Hyesook SON}

\section{Canon Formation and the Reception of Blake's and Dickinson's Poetry in Korea}

The concept of the literary canon of English literature in South Korea took shape around critical values competing with and contradicting one another. In general terms, Korean scholars identified literary studies in English as a source for the modernization of scholarship; however, the history of said canonization reveals various social, political, and cultural pressures and the canon itself has become the record of the changes, conflicts, and transformations Korea has undergone over the years. In the study at hand, I examine in post-1945 Korean literature the reception of William Blake's and Emily Dickinson's poetry with regard to the Korean literary system's social, cultural, political, historical, national, and generational demarcations. During Korea's version of New Criticism that was in place until the 1980s, Blake's poetry was considered an emblem of Korean literary nationalism, whereas the poetry of Dickinson was the only poetry by a woman poet canonized during said period.

To prevent the expansion of communist ideology and intervention, the United States occupied South Korea after the liberation from Japanese occupation in 1945 and installed the United States Army Military Government in Korea (USAMGIK). The division of the country brought much political and ideological tension and education, like many other areas of the country's social, political, and cultural sectors, became an arena for contending ideologies and perspectives. Since the Bureau of Education of USAMGIK introduced the US-American system of higher education, the Korean institutional infrastructure was re-organized accordingly and this has been the case also in the field of the study of literature. Interestingly, in the study of literature-i.e., mostly English-language literatures-the dominant theoretical framework Korean scholars adopted was New Criticism. However, few Korean scholars questioned the ideological implications of New Criticism and its constricted canon. Several aspects account for the acceptance of the model and these include the then objective to modernize in Korea the study of literature and the humanities in general and a practical need to employ a pedagogical method in order to accommodate the expanding student population and New Criticism allowed focus on only the formal aspects of the text. Of equal significance was the fact that New Criticism allowed the isolation of literary texts from social, cultural, and political contexts thereby shielding literary studies from any outside pressure during the Cold War. The ahistorical and apolitical character of New Criticism has frequently been seen as a sign of "objectivity" and "balance." Further, the involvement of USAmerican governance included that a high percentage of professors of English literature were educated in the U.S. and they accepted the established US-American canon and took New Criticism as the best approach to the study of English literature. For example, two of representative Korean scholars of the first post-1945 period of literary studies in English, Yang-ha Lee and Chul Paik, studied the work of new critics including I.A. Richards, John Crowe Ransom, Allen Tate, and R.P. Blackmur and translated their works to Korean (see, e.g., Kim, Yong-kwon). Thus in South Korea New Criticism became the dominant model in literary studies until the 1980s. Sangsup Lee's 1983 survey indicates that fortyseven percent of professors in departments of English believed that New Criticism was the best methodology for teaching English-language literature (271).

Not only in the period I am discussing here, but until recently Dickinson has been the only woman poet in the canon of Korean literary studies of English literatures because her scant biography, her withdrawal from society, and her reluctance to publish helped create an ideal text for the new critical close reading. The table below illustrates the number of publications related to thematic categories of Korean Dickinson scholarship:

\begin{tabular}{|l|c|c|c|c|c|}
\hline \multicolumn{1}{|c|}{ theme \& years } & $1970 \mathrm{~s}$ & $1980 \mathrm{~s}$ & $1990 \mathrm{~s}$ & $2000 \mathrm{~s}$ & total \\
\hline death & 3 & 9 & 8 & 6 & 26 \\
\hline $\begin{array}{l}\text { faith (immortality, } \\
\text { etc.) }\end{array}$ & 1 & 2 & 3 & 4 & 10 \\
\hline love & 1 & 2 & & 2 & 5 \\
\hline nature & & & 2 & 2 & 4 \\
\hline self, subject & & & 5 & 6 & 11 \\
\hline language & 3 & 9 & 5 & 2 & 19 \\
\hline $\begin{array}{l}\text { womens' experienc- } \\
\text { es }\end{array}$ & & & 5 & 8 & 13 \\
\hline
\end{tabular}




\begin{tabular}{|l|c|c|c|c|c|}
\hline $\begin{array}{l}\text { themes in compara- } \\
\text { tive literary studies }\end{array}$ & 1 & 3 & 3 & 7 \\
\hline $\begin{array}{l}\text { psychological theme } \\
\text { (pain, loneliness, } \\
\text { resignation, etc.) }\end{array}$ & & 4 & 4 & 8 & 16 \\
\hline philosophical themes & 4 & 5 & 1 & 4 & 14 \\
\hline other themes & 1 & 1 & & & 2 \\
\hline
\end{tabular}

Figure 1. Categorization of Dickinson's poetry based on publications listed in Korean Research Memory <http://www.kmr.or.kr>.

The chart of work published by Korean scholars on Dickinson's poetry suggests that the conventional categories made by the first editors of Dickinson in the 1890s and reinforced in New Criticism are still widely circulating in Korean scholarship. Dickinson's thematics-life, death, love, nature, time, eternity, and so on-have become the lenses through which Korean readers first encounter Dickinson. To understand Dickinson's poetry, Korean scholars used these themes through which to analyze her poetry although some have become "more sensitive to the implications of her metaphoric way of thinking" (Sewall 32) and thus acknowledged the problems of an easy categorization of themes in Dickinson's poetry. The reading, research, and teaching of Dickinson's poetry can be daunting to Koreans. Dickinson's ungrammatical textual structures-syntactical compression, disjunction, and metrical and prosodic innovations-and her characteristic diction, grammar, and syntax "prompt an intellectual, emotional, and sign-tracing agility in the reader" (Porter 184) and this is not an easy task for non-Englishspeaking readers. It is difficult to understand her terse, disparate poems without a reliable biographical background and without any contextual knowledge of her thematic preoccupations and conception of poetics. Deprived of any substantial information about her intellectual focus and intentions, Koreans turned to the formal analysis of New Criticism and the old categories without questioning the problem of the categorization itself.

While Korean new critics favored asocial, ahistorical texts and the "timeless" values of a few chosen poets, the nation's social, political, and ideological shifts began to expand the canon. During the 1970s, Korea saw rapid industrialization and economic development along which came various kinds of social turbulence, class division and struggle, and mass movements. All of these changes laid the groundwork for a project of Korean literary nationalism. As Yeong-min Kwon points out, the first theorized literary nationalism was a discursive response to "a need to search for the total meaning of the life of the nation and the recovery of its wholeness" in order to counter the national crises of the 1970s (521; unless indicated otherwise, all translations are mine). Paik likewise defines literary nationalism as a way to face the threat to "the nation's autonomous existence and the welfare of the majority of its people" (National 125). Paik's two works are cited in this article]. Even before literary nationalism emerged in the 1970s, nationalism had been the dominant political and cultural ideology in Korea that grew from the political and cultural struggle against Japanese imperialism. A mixture of modernity and pre-modernity, it emphasized ethnic, linguistic, and territorial unity and endeavored to preserve its idealized past. According to Yoon-shik Kim, the influence of nationalism is so critical that modern Korean literature is almost identified with "national literature" (319-20). The Korean Independence of 1945, the ensuing national division by the USSR and the U.S., and the Korean War of 1950 complicated the concept of nationalism. After the Korean War, the divided country in need of a liberal and progressive discourse of modernity incorporated the Western civic model into its native nationalism.

In the study and teaching of literature, the nationalism of 1970 s South Korea was, interestingly, in some instances based on Georg Lukács's theory of realism. According to Lukács, literary texts cannot be separated from their social, political, and historical contexts, and "true realism" always links the individual to the social whole and to "the significant movements of history itself" (Eagleton 28). Lukács argued that the study of literature should involve "an awareness of the development, structure, and goal of society as a whole" (96) and his concepts of totality, typicality, and concreteness gained currency in the 1970s (Pihl 333) and whether a text achieves typicality or reflects successfully its social reality has become a major criterion for a realist reading. Literary nationalism was further enriched by the debates on literary populism of the 1980s. The Kwangju Massacre of May 1980 (a popular uprising against Doo-hwan Chun's military dictatorship in the city of Kwangju) radicalized many students and 
resulted in mass protest movements. Further, Chun's and Tae-woo Roh's military regimes (19811993) brought about a sharp confrontation between society and the military powers. The belligerent milieu of the 1980s produced "a large crop of militant works and a fierce critical debate on the political function of art" (Paik 559). Extremist critics introduced socialist realism of the Soviet school and other radical discourses and literary populism emerged as an alternative to literary nationalism focusing on people's autonomy and ideological consciousness.

The rigid social and political realities of the 1970s and 1980s led to the predominance of nationalism in literary study and this situation included English literary studies as well. Most scholars dedicated to the nationalist cause during these two decades were male intellectuals who were exposed to Marxism and socialist aesthetics. Although they were few in number, their discursive power and active engagement in the political sphere endowed them with cultural authority and legitimacy. They preferred the nineteenth-century British novel to any other genre and they criticized New Criticism for its ahistorical methodology and kept their distance from poetry which they perceived as the favorite genre of the new critics. Poetry did not easily satisfy their standards of "typicality" or "reflecting reality." Therefore, there is relatively little scholarship or criticism of poetry in the nationalist reading of British and US-American literature. Even when nationalists addressed poetry, their choice of texts was limited: they preferred poets who were involved directly or indirectly with the French Revolution. When studying Modernism, Korean scholars of the nationalist bent preferred European modernists (who commented on the modern crisis in grand scale) to the US-American regionalists such as Robert Frost. While the study of poetry was generally neglected among nationalist critics and scholars, the work of Blake was widely appreciated as an example of "true realism." Blake was regarded as an initiator of activist poetics and a critic of the systematic oppression of people by monarchy, state religion, and all ideological apparatuses. The figures below show his popularity in Korean scholarship of the last four decades:
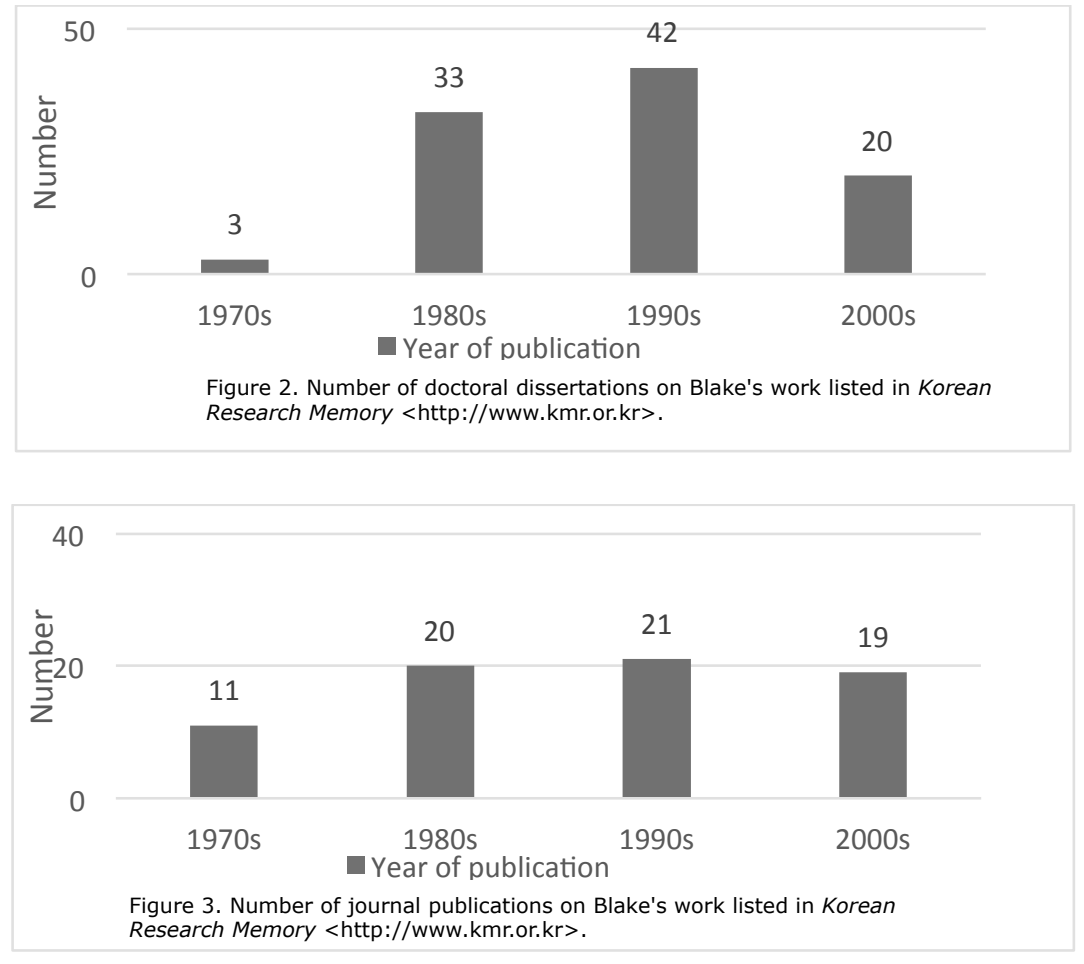

Both figures above show that there was a sharp increase in the number of studies of Blake's work not only written by graduate students, but also published in academic journals in the 1980s, although his popularity seems to have declined since nationalism lost its hold in the twenty-first century. Why, then, did Blake initially gain such popularity? Korean nationalists wanted to learn from Blake the answers to 
their most urgent questions such as how to build an ideal relation between the individual and society and how to avoid corrupt reality through imagination.

While living through a revolutionary era, Blake sought to dismantle the power that the corrupt community exerted over an individual. He suggested that the subversion of tyrannical oppression and the collective production of social reality by individuals are essential for a new community. His ideas perfectly correspond to Korea's historical experience of colonization, dictatorship, the mass protest movements against it, and the gradual advance towards democracy. Throughout his prophetic poems, Blake also illustrated a vision of a desirable community of diversity and heterogeneity where the "contraries" or oppositional collectives guarantee a social diversity to help the individual keep a critical distance from all forms of dominance. Most Korean Blakeans have cherished his vision as a referential pluralistic model for a rapidly modernizing nation-state. However, Blake's idea of time and history is not completely comparable with nationalist tenets because his apocalyptic redemption of history questions the linear flow of time and presupposes self-negating plural subjectivity as an agent of the rejuvenation of history. Korean nationalist discourse aims at constructing an autonomous subject and progressive model of time for the execution of the modernist project; however, Blake disrupts the notion of homogeneous time because it is simply "a strong conventional medium that naturalizes and even absolutizes emerging capitalism and the stable unitary liberal subject" (Ryu 13). This is the reason most realist readings of Blake during the 1970 s and the 1980s wavered in their evaluation of Blake's vision. For example, Kang-mok Suh maintained that Blake was/is an example of true realism, successfully incorporating the longing for a better world into his criticism of contemporary reality by engaging the reader's imagination in a more desirable reality (401). However, for Suh Blake did not elucidate how imagination works in the redemptive process of history, how it can be an alternative to an emancipatory feature of the Enlightenment, or how the process decenters the stable unitary self and constructs a self-negating plural subject for a creative and collective production of a new world.

Blake's ideas of history, redemption, and imagination destabilize the foundation of nationalism, challenge the premise of modernity and decenter the rational subject as an agent of it. If nationalism fails to fully elucidate Blake, then how can it be a relevant discourse of the twenty-first century or cover a wider range of poets than before? Can it offer a usable perspective to the age of globalization? How should it meet the massive social shifts toward pluralism and multiculturalism? Can it be a reliable futuristic model to foster a new picture for Korean literary studies in English? Korean Blakeans of the twenty-first century are facing a new challenge from inside the academy, a challenge that asks how to mobilize postmodern insights "for the service of a more inclusive form of sociality" (Ryu 136). Korean scholars are open to postmodern theories and discourses and are willing to incorporate divergent contemporary literary theories into indigenous nationalism. Instead of interpreting Blake as a model of modernization and a centralized nation-state, they utilize Blake for a developing, pluralistic nation, and try to broaden the concept of realism and national literature for the postmodern age.

While literary nationalism has evolved as a representative counter-discourse for four decades, New Criticism has kept its critical power as a mainstream ideology in literary studies in English. The two approaches are opposites in their cultural politics and preference of literary genre. However, in my view in each there is an autonomous male subject producing and circulating the discourse and executing the project. One structures the segregated aesthetic domain, performs formal analysis, and shores up the established canon of the literary corpus. The other responds to economic and political changes in the capitalist world system, connects the literary with the real, combines the text with the context, and attempts to reconstruct national entity through language and literature. However, both are based on the same anti-woman assumption similar to the scholarly discourses of the East Asia (see, e.g., Kim, Eun-Shil). The mediation of gender politics, therefore, is an important factor in evaluating these dominant critical ideologies under whose hegemonic power other differences were suppressed or erased in Korea's history. The division of the country, the extreme political and social upheavals, and rapid economic development and industrialization legitimized masculine culture and justified maledominated intellectualism, nationalism, and the sexually biased interpretation of women in literary studies. Considering the 500-year history of Korean patriarchy, however, it is not surprising to see its legacy resurging in the modern nation-state in the form of male-dominated discourses. The Korean patriarchy was established ideologically during the Chosun Dynasty $(1392-1910)$ during which time state and family were two major apparatuses for the operation of patriarchal principles and practices 
(see, e.g., Lee, Sang Wha). The tenets of Confucianism imported in the fifteenth century provided parochial male dominance with an ideological base and an effective way to legitimize gender hierarchy and force it upon Korean society and culture. The traditional Confucian patriarchy of Korea confined women's sphere within home and family and identified domestic virtues like loyalty, filial piety, and chastity as belonging to the female realm. Further, in this model women were linguistically silenced and structurally marginalized under the systematic operation of its ideology.

Until the 1980s, traditional Confucian patriarchy influenced most male Korean scholars of English literature regardless of their political or cultural orientation. They suppressed the feminine in the formation of critical discourses without any serious self-reflection. They identified consciously and/or subconsciously the feminine as a rejection of idealism, literary experimentalism, and academic militarism, therefore erasing most women authors from the literary canon. Male Korean scholars received the established US-American canon of the 1940s, which was made by college-educated White men of Anglo-Saxon or European origins (see, e.g., Lauter, "Race" 442). When Korean scholars received the sexually biased US-American curricula of the 1940s, they further scaled back the number of authors and thereby reduced foreign literature to a "manageable" size thus no woman poet other than Dickinson was found in any basic English literature college course or textbook. Nor was any female writer found in any standard Korean volume of literary bibliography or criticism until the 1990s. In his 1994 review of the curriculum of literary studies in English, Geo-yong Park observed that almost the same curriculum consisting of the same authors and the same works was used in Korean universities and colleges from the 1960s to the 1990s (158). Social and historical factors combined with indigenous patriarchy created a hardened and biased canon of English literary studies that was accepted as legitimate by Korean scholars until the 1990s.

The upheavals of the 1980s were pivotal in restructuring the calcified English literary canon of Korean scholarship and pedagogy. The success of mass protest movements in June 1987, seven years after the Kwangju Massacre, opened the way toward political democratization. It showed that Korean society had finally achieved "the capacity to control state via autonomous and enduring civil disobedience" (Chung 234). Throughout the pro-democracy movements of the 1980s, various subgroups within the movement's organizations competed with one another and feminist research was among them. Korean feminists were involved with the democratization movement and they shared nationalist tenets and the modernity project with other groups despite of their different political and intellectual goals. During the period of mass mobilization and pro-democracy movements, the question of gender inequality could not be easily foregrounded; however, the political transformations of 1989-1991 and the following successful democratic transition brought changes to Korean civil society and provided an outlet for Korean feminists.

Korean feminist criticism and scholarship achieved their academic identity through researching and teaching about women and through diverse collaborative work with feminists in different disciplines and fields of study during the 1980s. The Korean Association of Women's Studies was founded in 1985 and the Korean Association for Feminist Studies in English Literature was established in 1992. Feminists introduced Western feminist theories and the work of women authors by promoting them in institutions of higher learning, as well as in the publishing market. While doing that, they attempted to discover cultural alternatives and create another system of representation and expression for women. They also tried to restructure the academic paradigm, criticized the literary canon created in Western scholarship and exposed the ideological operation of male value judgments. While changing the literary canon to include a significant number of women and minority authors, they have questioned the male dominance of the Korean academic world and deconstructed the patriarchy embedded in Korean culture, language, and consciousness. Feminist academic practices of the 1980 s reflect their increasing number and power in Korean scholarship. Until 1977, the proportion of women was less than ten percent of the total number of Korean scholars. Further, women scholars were left without any significant organizational base and were excluded from leadership positions and from any scholarly power structure within the academy. However, the increase of women in the field of higher education since the 1980 s-brought on by demographic changes and the development of the modernization of the Korean educational system-enabled Korean women scholars to compete more effectively with men for professional positions. In 2008, women earned forty-two percent of all doctorates for literary studies in English and the proportion of women professors rose to twenty-seven percent (based on material in 
Korean Research Memory). However, the increase in numbers does not necessarily guarantee the equal growth of women's power in academia. Women are still less competitive than men in Korean occupational markets and most academic institutions prefer male "bread-winners" to women and do not question the validity of favoritism toward men. The amount of research about women authors has also increased since the 1980s, as can be seen in the figures on Dickinson below. However, even the study of the most widely canonical woman poet shows an apparent limitation of gender research in Korea.
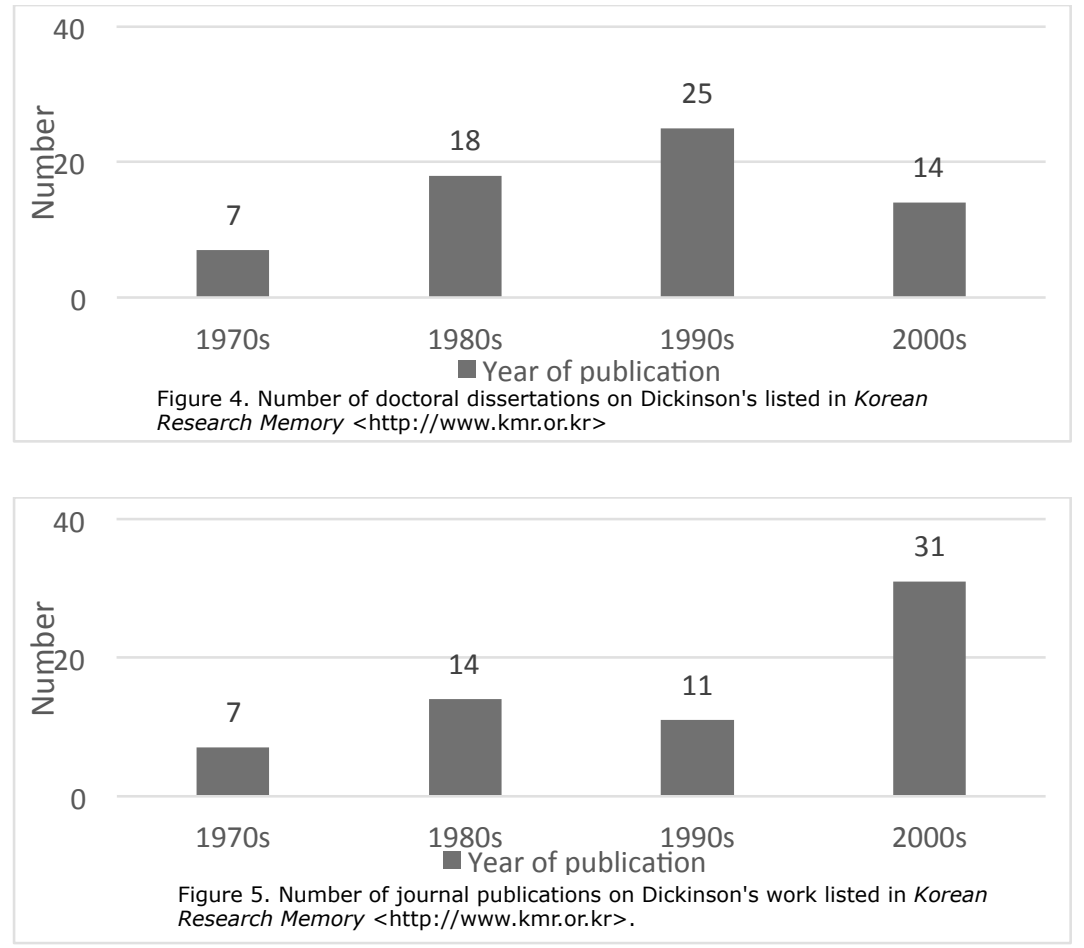

There was an impressive growth in the number of publications on Dickinson starting in the 1980s, that is, more than double that of the previous decade. However, comparing the total number of publications on Dickinson with that of Blake, we can see that Dickinson's work drew less attention than those by Blake. While this does not indicate bias as the cause of the imbalance between studies on Blake and Dickinson per se, the patriarchal milieu (academic and social) does indicate at least some relationship. Figure 6 sums up the imbalance:
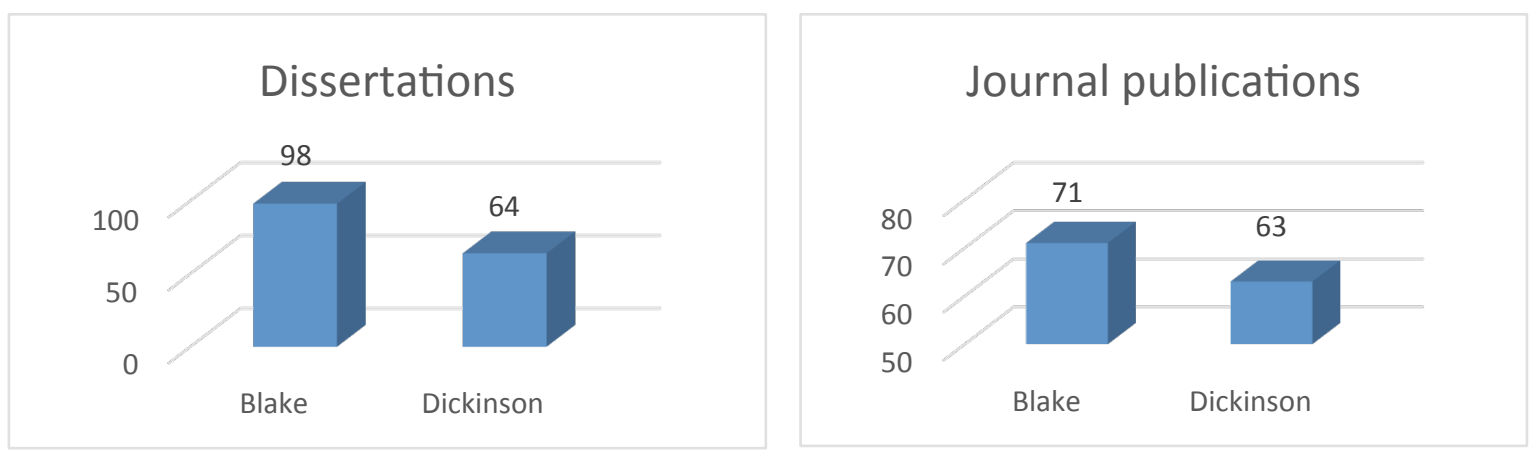

Figure 6. Total number of publications from the 1970 s to the 2000 s on the work of Blake and Dickinson listed in Korean Research Memory $<$ http://www.kmr.or.kr> 
The total number of masters theses and doctoral dissertations on Blake from the 1970s to the 2000s is 98 , thus about $33 \%$ more than that on Dickinson. The number of journal publications on Blake of the same period is 71 , almost $12 \%$ more than the number published on Dickinson's work during the same period. This result is somewhat surprising when we consider the cultural and pedagogical power of New Criticism in Korean scholarship, the importance of Dickinson in the constricted literary canon of New Criticism, and the relative paucity of English poetry scholarship among scholars of the nationalist bent. Hence the question as to what would have caused this result and how can we interpret it? There may be several reasons for this, for example as I mention previously Dickinson could have been more difficult to study and teach than Blake for most Koreans.

Next, I discuss the underdevelopment of gender studies in Korea as at least one of the factors in explaining the imbalance between the amount of scholarship devoted to Dickinson's texts in favor of those of Blake. They interpreted her as genuinely feminine: like one of those upper class women of the Chosun Dynasty, she was chaste and loyal, attached to her home, cloistered during her lifetime, uninvolved with any worldly concern, and dead when her poems were published and circulated in the outside world. As an "unthreatening virgin," she became a site for the transference of Korean male bias toward the foreign woman poet. In addition, Dickinson scholarship has been influenced by antiwomen processes in canon formation inherent in New Criticism. For example, Blackmur dismisses and disparages Dickinson because female experience is not sufficient "to authorize the texts as embodiment of a lived personal identity" (Blackmur qtd. in Morris 78) and Tate, the most favored authority on Dickinson in Korean scholarship, disembodies and desexualizes Dickinson by praising her commitment to her mind as a true realm of intellectual struggle. Tate's idea echoes, for example in one male Korean scholar's assertion that Dickinson's withdrawal from society is a longing for the loneliness which enables her to elevate her personal experiences into the realm of the absolute (Kim, Chul-Soo 19). Whether rejecting or promoting her, new critics share the same assumption that "poetry should reflect what T.S. Eliot called 'direct sensuous apprehension of thought'" (Morris 75): Tate observed that Dickinson's precision of statement is "due to the directness with which the abstract framework of her thought acts upon its unorganized material" (26). New Criticism takes no account of the concerns of gender or context and privileges formalist abstraction.

The anti-woman stance of New Criticism combined with Korean patriarchal culture twisted the interpretation of Dickinson: some insisted that her poetic achievement is a compensatory act for her unfulfilled womanhood and others interpreted her withdrawal from society as a failure to face the contingency of the world and regarded her language as a self-referential entity separate from outside reality. Prior to the late 1980s, Dickinson scholars in Korea disregarded the nature of female experience and creativity and assumed Dickinson's life and art to be abnormal, deficient, or at least eccentric. One male scholar maintained that Dickinson lacked "the insight on the paradoxical coexistence of individuality and universality which modern American poets finally reached" because of her obsessive attention to "her single self" (Park, Jae-Yul 192). The sexist norms of Korean patriarchal culture, masculine nationalism, and ahistorical New Criticism all sanctioned and encouraged the biased, gendered interpretation of Dickinson and starting in the 1980s Korean feminist scholars challenged sexist norms and combined Dickinson's life and art in its historical, cultural, psychological context. However, in my opinion they went to another extreme by focusing narrowly on the incarcerated female self. They often underlined more of their rectified gendered version of Dickinson and failed to appreciate her full textual potential. Mi Seon Yoon, for example, argues that Dickinson's renunciation is a strategy to empower her female self and a way to resist patriarchal values and disrupt cultural constraints (60). Yoon's argument is a typical Korean feminist statement asserting that poetic language crystallizes its difference under pressure of, and in diacritical tension with, a normative cultural discourse. However, when it comes to a poet such as Dickinson, the feminist's notion of power as resistance sounds too prosaic or belligerent to cover the numerous occasions where the self is radically dialogic, discontinuous, inconsistent, or unstable. There are ample reasons, of course, for Korean feminists' version of a female self: they need a model for an empowered female subject to question gender discrimination and repression in order to rewrite literary history, to redesign the cultural and educational system, and to gain more power in discourse, pedagogical apparatus, employment, and cultural reproduction. However, reinforcing the female self is one thing and coercing the desirable female self upon the text is something else. To challenge the existing patriarchy and construct a new discursive system through continuous prac- 
tices in twenty-first century's pluralistic society, Korean Dickinson scholars need to appreciate her plural, polyphonic, and choral voices and hence I suggest that they need to make the notion of female self more flexible and extensive and not to sacrifice the full textual potential of women's creativity.

Changes have already taken place among a new generation of Korean Dickinson scholars. For example, Jung Hee Kim assumes that Dickinson avoids intentionally any authorial statement to make her self unstable and therefore suitable for her epistemological quest (150). Jae-Yul Park, likewise, posits that the instability of Dickinson's self originates from her acceptance of the bodily and semiotic elements threatening apparent unity and stability of self (47). Although their thematic concerns and theoretical backgrounds vary, Korean Dickinson scholars of today are more open to new fields of Dickinson studies. Debates on such things as her manuscripts and letters, her reception and influence, her poetics and historical context, and her eroticism are waiting to be explored by Korean scholars who are willing to enrich their literary soil by appreciating female experience and creativity.

In conclusion, the canon of English-language literature in Korean scholarship is changing and this includes poetry both as primary and secondary literature. The reception of Blake's and Dickinson's work has symptomatically displayed the characteristic Korean interpretive frames working through the last six decades and their limits and inherent possibilities. Today, Korean scholars are examining both their literary inheritance and reconstitute literary scholarship in general in order to reflect the shifting historical and cultural conditions to meet the need for change and diversity.

Note: Research for "Canon Formation and the Reception of Blake's and Dickinson's Poetry in Korea" has been funded by the 성균학술연구비 (Sungkyun Research Fund, Sungkyunkwan University, 2011).

\section{Works Cited}

Chung, Chulhee. "Social Movement Organizations and the June Uprising." Korean Politics: Striving for Democracy and Unification. Ed. Korean National Commission UNESCO. Elizabeth: Hollym, 2003. 233-54.

Eagleton, Terry. Marxism and Literary Criticism. Berkeley: U of California P, 1976.

Kim, Chul-Soo. "A Longing for the Absolute Loneliness: The Poetry of Emily Dickinson." New Studies of English Language \& Literature 8 (1997): 1-17.

Kim, Eun-Shil. "Women and Discourse of Nationalism: Critical Readings of Culture, Power, and Subject." Women's Experiences and Feminist Practices in South Korea. Ed. Pilwha Chang and Eun-Shil Kim. Seoul: Ewha Women's UP, 2005. 29-65.

Kim, Jung Hee. "'A Syllable-less Sea': Epistemological Problems in Emily Dickinson's Poetry." The Journal of English Language and Literature 51.1 (2005): 145-68.

Kim, Yong-kwon (김용권). 영문학 교육과 연구의 문제들 (Problems in Teaching and Studying English Literature). Seoul: Hanshin, 1996.

Kim, Yoon-shik. "The Korean Novel in the Age of Industrialization." Korean Literature: Its Classical Heritage and Modern Breakthroughs. Ed. Korean National Commission UNESCO. Elizabeth: Hollym, 2003. 319-27.

Korean Research Memory <http://www.krm.or.kr>.

Kwon, Yeong-min (권영민). 한국 민족문학론 연구 (Studies in Korean Literary Nationalism). Seoul: Mineumsa, 1988.

Lauter, Paul. Canons and Contexts. Oxford: Oxford UP, 1991.

Lauter, Paul. "Race and Gender in the Shaping of the American Literary Canon: A Case Study from the Twenties." Feminist Studies 9.3 (1983): 435-63.

Lee, Sang Wha. "Patriarchy and Confucianism: Feminist Critique and Reconstruction of Confucianism in Korea." Women's Experiences and Feminist Practices in South Korea. Ed. Pilwha Chang and Eun-Shil Kim. Seoul: Ewha Women's UP, 2005. 67-115.

Lee, Sangsup. "Problems in Teaching English Literature in Korea." The Journal of English Language and Literature 32.2 (1986): 269-95.

Lukács, Georg. Realism in Our Time: Literature and the Class Struggle. Trans. John Mander and Necke Mander. New York: Harper \& Row, 1964.

Morris, Timothy. Becoming Canonical in American Poetry. Urbana: U of Illinois P, 1995.

Paik, Nak-chung (백낙청). 민족문학과 세계문학 (National Literature and World Literature). Seoul: Changbi, 1978.

Paik, Nak-chung. "Zen Poetry and Realism: Reflections on Ko Ūn's Verse." Positions 8.2 (2000): 559-78.

Park, Geo-yong (박거용). 영어교육과 연구의 문제들 (Problems in Teaching and Studying English). Seoul: Hanbit, 2004.

Park, Jae-Yul. "Abjection in Emily Dickinson's Poetry." British and American Language and Literature 55 (1999): 23-47.

Park, O-bog. "Triumph through Knowledge in Emily Dickinson's Poetry." Theses of Suncheon National University 4 (1985): 183-94.

Pihl, Marshall R. "The Nation, the People, and a Small Ball: Literary Nationalism and Literary Populism in Contemporary Korea." Korean Literature: Its Classical Heritage and Modern Breakthroughs. Ed. Korean National Commission UNESCO. Elizabeth: Hollym, 2003. 329-45.

Porter, David. "Searching for Dickinson's Themes." The Emily Dickinson Handbook. Ed. Gudrun Grabher, Roland Hagenbüchle, and Cristanne Miller. Amherst: U of Massachusetts P, 1998. 183-96. 
Ryu, Son-moo. "Imagining Society: William Blake, William Wordsworth, and George Eliot." Diss. Indiana University, 2005.

Sewall, Richard B. "Teaching Dickinson: Testimony of a Veteran." Approaches to Teaching Dickinson's Poetry. Ed. Robin Riley Fast and Christine Mack Gordon. New York: Modern Language Association of America, 1989. 3038.

Suh, Kang-mok. "The Achievement of Realism in Blake's Jerusalem." English Literature in the Global Era. Ed. Junkyu Seol and Myeong-hwan Kim. Pajoo: Changbi, 2004. 389-414.

Tate, Allen. "Emily Dickinson." Emily Dickinson: A Collection of Critical Essays. Ed. Richard Sewall. Englewood Cliffs: Prentice-Hall, 1963. 16-27.

Yoon, Mi Seon. "Emily Dickinson's Aesthetics of Renunciation." Modern Studies in English Language \& Literature 48.2 (2004): 43-62.

Author's profile: Hyesook Son teaches English-language literatures at Sungkyunkwan University. Her interests in scholarship include US-American literature and poetics. In addition to numerous articles in Korean and English, Son's book publications include Alterity and the Lyric: Heidegger, Levinas, and Emily Dickinson (2007) and Literature and Spirituality in the English-speaking World (2014). E-mail: <hyesookson@skku.edu> 